"unlucky paper" should be openly exposed, than that I should be "damned with faint praise."

IHull, April 8

C. Staniland Wake

\section{The Aurora of February 4}

THE Scottish Meteorological Society has just received the scliedules of its observers in Iceland and Farö for February last. At Stykkisholm, on the north-west of Iceland, auroras were seen on each of the nights of the $3 \mathrm{rd}, 4^{\text {the }}$, and 5 th, and at Thorshavn an aurora of a remarkably red colour was observed in the S.E and $S$. in the evening of the 4 th. It was also observed at $\mathrm{N}$ orth Uist, Shetland, of a very red colour, and over all the S.E. of the sky; at Monach, the most western island of the Hebrides, and at nearly all the I 50 stations which report to the Society, appearing at some places as early as 5 P.M., and continuing visible at others till half-past one on the morning of the 5 th. Major Stuart, the Society's observer at Janina, Greece, also reports an aurora on the $4^{\text {th }}$ from 6.30 P.M. to midnight.

On the evening of the 4 th much thunder and lightning occurred in Monach, South Uis?, Skye, and others of the Western Isles, and on the mainland of Scotland adjacent, even as far inland as Corrimony, fifteen miles west of Loch Ness.

The weather preceding and following this aurora was very remarkable. At Stykkislolm, $22^{\circ} 43^{\prime} \mathrm{W}$. long., the mean height of the barometer from the 3 oth of January to the 5 th of February was only 28.798 inches, and the wind N.E. throughout, except on one of the days, when it was E. At this same place a storm of wind, with snow showers, began at $x$ A.M. of the 3 oth of January, and continued without intermission for IO2 hours, or till $7 \mathrm{~A}$. M. of the $3 \mathrm{rd}$, on which day and on the $4^{\text {th }}$ the weather was fine and seasonable and the $u$ ind light.

At Monach, $7^{\circ} 34^{\prime} \mathrm{W}$. long., a storm of wind began at $6 \mathrm{~A}$.M. of january 30 and continued to blow from Wr.S.W., S.W., and S. till 2.30 A.M. of February 5, having thus lasted about 140 hours.

On the west of Scotiand and the Western Isles, a heavy storm of wind from S. or S.W. was bluwing during the evening of the $4 \mathrm{~h}$, the sky being generally clear, and the aurora, consequentiy, well sten. But at some places the sky presented a strange lurid appearance, as the aurora appeared through the opening clouds as they drifted part. Shortly after the disappearance of the auroria, the wind modera'ed and fine weather followed.

But in the east of Scotland the storm from the south, accompanied with drizzle and mist, did not break out till the moming of the $5 \mathrm{~h}$, or some time after the aurora had disappeared. It was to have been expected that an aurora extending over so much of the e.rrth's surface would be preceded, accompanied, and followed by very different weather in different regions; and we have seen it coming thirty-six hours after a protracled period of stormy weather in Iceland, closing an equally protracted period of stormy weather in West Hebrides, and preceding a storm of wind and rain in the east of Scolland.

\section{Alexander buchan}

\section{Scottish Meteorological Society, Edinburgh, April 8}

HAVING seen an account of the aurora borealis which was visible in England on the night of February 4, I think that you or some of your scientific friends might like to know that a very brilliant display of aurora was visible here and in other parts of the West Indies on the same night.

On the night of February 4, I was going from Porto Rico to Puerto Plata in, roughly speaking, lat. $19^{\circ} \mathrm{N}$., long. $48^{\circ} \mathrm{W}$. The aurora was first seen at 8.30 P.M., was most brilliant at IO P.M., and gradually died away by midnight; the corresponding times at Greenwich would have been I A.M., 2.30 A.M., and 4.30 A.M., February 5 .

I have several times seen auroras off the Western Islands, but only remember havirg seen one several years ago in the West Indies.

There were no pillars or points of light in this aurora, but a bright flush in the northern sky, which surged up and died away again every now and then, and was brightest about IO P.M.

H.M.S. Mersey, St. Thomas, March I4 STEPHEN DIX

THE aurora of February 4 was visible at this point, but seems to have been unobserved, except by a very few. My position was on the deck of a steamboat on the river going from this point to one 23 miles miles higher up. The aurora was first noticed by me at about 7 P.M., hanging over the woods to the north-east, and was mistaken by the Captain for a large fire, a common occurrence in our pine forests. Soon after, the glow, which was a very deep red, extended to the zenith, shading of there, whilst a much fainter red light appeared in the north. west.

My last observation was made at 8.30 P.M., and the light was then still very strong in the north-east. Being then upon a train, and passing through an unbroken pine forest, I could not note the time of disappearance of the display. I saw no streamers.

There was no aurora whatever to the south at any time visib'e from at least sunset to 8.30 P.M. The facilities for observing the sky in that direction were peculizrly favourable from the position upon the river.

Mobile, Alabama, U.S.A, March 23

\section{On the Colour of a Hydrogen Flame}

A CORRESPONDENT to your last number has troubled himself to propound an elaborate theory, to account for the blue tinge which he states is always exhibited by the flame of hydrogen. There are also several text-books on chemistry which assert that hydrogen burns with a characteristic faint blue flame. It is easy to prove, however, that the flame of pure hydrogen has no blue tinge whatever. The blueness so frequently associated with the flame of hydrogen is really due to the presence of sulphur, as is shown in a little paper I published in the Hhilosophical Magazine for November 1865.* It is possible that the facts mentioned in that paper may be turned to a praclical end by some of your readers, and therefore it may not be altogether useless if $\mathrm{I}$ put down-for such disposal as you deem proper-one or two interesting phenomena associated with the combustion of hydrogen.

There must I imagine be some people who write text-books or experimental science without having verified any of the facts they state. Otherwise one cannot account for some obvious errors which are propagated from one writer to another. The bluenes; of a hydrogen flame is one such error, and another still more g'aring can be traced back through several high authori. ties. The fact is stated that a rod of iron, or a sewing needle, remains suspended in the centre of a helix of wire through which an electric current is passing. So long as the helix is animated by the current the iron is said to behave like Mahomet's coffin, and hang in the air without the least contact with any solid body. But this is not the case, however strong the current, or small the iron, or however the helix may be disposed.

More serious errors than these are to be met with in some of the little books on science for school use, that are now cropping up like mushrooms. Heads of schools cannot exercise too much caution in the introduction of text-books on science, for they know how a poor class book once in a school is a most difficult thing to eject. It is therefore impossible to over-estimate the value of books for boys written by men like Profs. Huxley, Roscoe, and Balfour Stewart. An extraordinary impulse to scientific teaching has been given by the manuals of these and other eminent authors, and of the gladness with which such books are received by elder boys I, like others, can testify.

And now, as a teacher, permit me, Sir, to tender to the same authors not only my own gratitude, but the genuine and hearty thanks of younger boys for their simply delightful Science Primers.

International College, Spring Grove, W.

[We hope to give in our next number a summary of the experiments to which our correspondent alludes.--ED.]

\section{Barometric Depressions}

I HAVE only just seen Mr. Murphy's criticism on my paper, which appeared in your columns on the 2 Ist ult. I intended that paper as a continuation of one which appeared last year. The former aimed at showing that the ordinary variations of the barometer could not be explained by aqueous vapour ; the latter at proving that they were accounted for by the heating and cool. ing of dry air. Into this question of air versus vapour the earth's rotation did not cnter, and I consequently took no account of it

* A year or two ago I was surprised and amused to read this investigation repeated in the pages of the Comptes Rendus. I forget the name of the French chemist who contributed it to the Academy, but he was doublless unaware of anything I had written on the subject. 